\title{
The world city network: evaluating top-down versus bottom-up approaches
}

\author{
Stefan Lüthi*1, Alain Thierstein**, Michael Hoyler*** \\ * Lucerne University of Applied Sciences and Arts, Institute for Management and Regional Economics \\ IBR, Zentralstrasse 9, CH-6002 Lucerne, Switzerland \\ ** Munich University of Technology, Territorial and Spatial Development, Arcisstr. 21, D-80333 \\ Munich, Germany \\ *** Loughborough University, Department of Geography, Loughborough, Leicestershire, LE11 3TU, \\ UK \\ ${ }^{1}$ Corresponding author: e-mail: stefan.luethi@hslu.ch
}

\begin{abstract}
The growth of the knowledge economy has led to new forms of business networks linking cities and towns across different spatial scales. Various attempts have been made to analyse these networks empirically using the interlocking network model of the Globalization and World Cities (GaWC) research network. Two approaches can be distinguished from a spatial perspective: a global 'topdown' approach that studies the world city network from the perspective of the largest advanced producer service firms, and a macro-regional 'bottom-up' approach that starts with the most important knowledge-intensive firms located within specific territorial boundaries. This paper compares and critically assesses the methodological implications and empirical outcomes of both approaches with reference to case studies of the German space economy. Both approaches pursue similar objectives: to investigate external relations of cities, both transnationally and on the national scale. Differences exist in the theoretical argumentation: the top-down approach is grounded in world city research; the bottom-up approach is anchored in debates in regional science and economic geography. In this paper, we argue for the need of scale-sensitive interpretations of connectivity patterns resulting from different approaches to the interlocking network model and conclude with some tentative recommendations for the methodological direction of future research in world city network studies.
\end{abstract}

Keywords: world city network, Germany, interlocking network model, scale, knowledge economy 


\section{Introduction}

Various attempts have been made to analyse city networks empirically using the interlocking network model (INM) devised by Taylor (2001) and subsequently employed in a wide range of studies by the Globalization and World Cities (GaWC) research network (www.lboro.ac.uk/gawc) and beyond (Derudder and Parnreiter 2014; Sigler and Martinus 2016; Martinus and Tonts 2015; Chow and Loo 2015).

In its initial specification, the INM is conceptualized as a global top-down approach that facilitates the study of the world city network from the perspective of the largest advanced producer service (APS) firms, which are interpreted as key economic actors in world city network formation (Taylor 2004). However, the INM has also been conceptualized using a bottom-up approach, analysing the office networks of the most important APS firms located within specific territorial boundaries in order to evaluate functional urban hierarchies in regional or national urban systems.

What is missing from the literature is a systematic critical assessment of the methodological implications of using a top-down or bottom-up approach to studying the world city network. Taking this deficit as starting point, this paper investigates the following research question: What are key advantages and limits using a top-down or bottom-up approach for the analysis of cities in a macroregional or national context? We start with the hypothesis that the main advantage of the top-down approach lies in its provision of global data in order to compare primary cities on a global scale. The bottom-up approach, on the other hand, provides more differentiated and meaningful results to explore city-regional and national divisions of labour in advanced producer servicing.

The paper is structured in four sections. Following this introduction, the second section briefly outlines the general analytical framework of the INM as well as its application as top-down and bottom-up approach. Section three presents the specific empirical settings and main analytical findings of the top-down and bottom-up analyses of the German urban system. In the fourth section, we discuss some tentative recommendations for the methodological direction in using the INM and conclude with key benefits and limitations of both approaches for the analysis of cities in a national context.

\section{The interlocking network model}

The INM has its origin in the early critique of an empirical and conceptual deficit in the literature on global and world cities. Taylor (1997) argues that many of these concepts concentrate simply on measuring data on world city attributes, while ignoring the critical importance of the relations within the global urban system. Taylor (2001) subsequently developed the INM to specify the 'world city network' based on the relationships between head offices and other internal offices of major APS firms operating across the world. The INM provides one specific way of addressing the question how inter-city relations can be empirically measured despite the chronic lack of data on inter-city flows.

Today, the INM is applied at global, national and regional scales and with different firm samples. Some authors use the largest APS companies in the world to document the integration of cities into the world city network (top-down). Others run the model with the largest APS companies in individual countries or regions. As shown in Table 1, both approaches - top-down and bottom-up are widely used at the national scale. This provides an opportunity to directly compare the results 
and to evaluate advantages and limits of both approaches in analysing the global integration and functional urban hierarchy in national urban systems.

Table 1: Application of the INM on different spatial scales (selected studies focusing on APS)

\begin{tabular}{|c|c|c|}
\hline & Top-Down & Bottom-Up \\
\hline Global Scale & $\begin{array}{l}\text { Taylor } 2001 \\
\text { Taylor } 2004 \\
\text { Taylor et al. } 2011 \\
\text { Taylor et al. } 2013 \\
\text { Taylor et al. } 2014 \\
\text { Taylor and Derudder } 2016 \\
\text { Derudder and Taylor } 2017 \\
\text { Yang et al. } 2017\end{array}$ & \\
\hline National Scale & $\begin{array}{l}\text { Taylor et al. } 2011 \\
\text { Hoyler } 2011 \\
\text { Derudder et al. } 2013\end{array}$ & $\begin{array}{l}\text { Taylor et al. } 2009 \\
\text { Schmitt and Smas } 2012 \\
\text { Lüthi et al. } 2013 \\
\text { Zhao et al. } 2015 \\
\text { Growe and Volgmann } 2016\end{array}$ \\
\hline Regional Scale & & $\begin{array}{l}\text { Taylor et al. } 2008 \\
\text { Hoyler et al. } 2008 \text { b } \\
\text { Thierstein et al. } 2008 \\
\text { Lüthi et al. } 2010 \\
\text { Zhang and Kloostermann } 2016 \\
\text { Lüthi et al. } 2016 \\
\text { Bentlage et al. } 2016 \\
\text { Zhang } 2017\end{array}$ \\
\hline
\end{tabular}

The interlocking network model as a top-down approach

The global top-down approach is based on three major theoretical concepts. The first is John Friedmann's (1986) world city hypothesis, which describes the rise of a transnational urban network referring to a major geographical transformation of the capitalist world economy, the production systems of which are increasingly internationalized. This reconfiguration results in a new international division of labour whose main agents are transnational corporations with complex spatial and organizational structures. According to Friedmann (1986), the presence of these transnational enterprises makes world cities "basing points in the spatial organization and articulation of production and markets" (Friedmann 1986: 71).

The second concept is Saskia Sassen's global city model, which associates cities with their propensity to engage with the internationalization and concentration of APS firms in the world economy (Sassen 1991). Through their transnational spatial strategies, APS firms create world-wide office networks covering major cities in most or all world regions, and it is this very multitude of connections between these service complexes that gives rise to the formation of transnational urban systems and leading global cities such as New York, London and Tokyo (Sassen 2001).

The third theoretical building block of the INM is Manuel Castells' immensely influential concept of a space of flows in the network society (Castells 1996). The main point of Castells' argument is that technological networks have given rise to a shift from a world economy to a global economy with the capacity to work as a unit in real time on a planetary scale. A consequence of this emerging global economy is a new spatial logic that is determined by the pre-eminence of the space of flows over the space of places (Castells 2000).

Based on these theoretical approaches, the INM was originally devised to allow the identification of the globally most integrated nodes in advanced producer service networks, and to provide a more 
inclusive perspective on cities in globalization that takes into account hundreds of cities across the world rather than focus on a few cities perceived to be atop an 'urban hierarchy'. Recent studies taking such a top-down perspective are Taylor et al.'s (2011) comprehensive mapping of the external relations of 525 cities worldwide, Taylor et al.'s (2013) new world regionalization based on APS location strategies, and Taylor et al.'s (2014) analysis of strategic networks and places. In recent years, the INM has also been used to analyse the uneven geographies of the world city network and to track changes over time on a global scale, for example in the context of the recent financial and economic crisis (Derudder et al. 2010; Hanssens et al. 2011; Liu et al. 2014; Derudder and Taylor 2016).

However, the data gathered on the locational strategies of the most important APS firms globally can also be used to analyse cities at other scales. For example, Taylor et al. (2011) provide a detailed analysis of city connectivities at world-regional and national scales, highlighting substantive contrasts in the integration of major regions and states into the world city network. At the national scale, global network connectivities adhere broadly to the importance of a city in its national context but there are significant differences between countries dominated by a primate city (e.g. the UK) and those with a more balanced urban network (e.g. Germany).

\section{The interlocking network model as a bottom-up approach}

The bottom-up approach of the INM is anchored in debates in regional science and economic geography. It is used very heterogeneously and is often combined with other data (e.g. Münter 2011, Growe and Blotevogel 2011, Lüthi et al. 2010). It treats world cities as more than simply centre-cores; they are viewed as complex functional urban regions, encompassing several cities, networked in a polycentric regional or national urban system (Scott 2001) driven by a spatial up-scaling of agglomeration economies (Lüthi 2013). This process is highly determined by the achievements realized in transportation and telecommunication technologies. Hall (2009), for example, emphasizes that the costs of several modes of transport and communication have drastically declined and, in some cases, speed and reliability have significantly improved. New infrastructures in the form of high-speed trains stimulate the transformation of relations in time and space and further the dispersal of urban development (Hall 2009).

However, traditional physical measures of functional regions - such as commuting catchment areas are only partially relevant at the macro-regional level. Another integrating force is non-physical business linkages. The combination of physical and non-physical forms of connectivity implies a huge complexity and sophistication of polycentric urban systems. Even tough traditional meeting points in the city centre keep their importance, they tend to be supplemented by new kinds of nodes for faceto-face interaction for example conference centres at airports of high-speed train stations (Hall 2001).

Pioneered in the European INTERREG IIIB research project POLYNET - Sustainable Management of European Polycentric Mega-City Regions (Hall and Pain 2006; Hoyler et al. 2008a) - Taylor's INM was utilized to analyse the world city network from the perspective of multi-locational APS firms situated within specific territorial boundaries. This city-regional approach has been used to document the integration of specific macro-regions and national urban systems within the world city network (e.g. Hoyler et al. 2008b; Taylor et al. 2008; Taylor et al. 2009). 
Recent studies taking such a bottom-up perspective are, among others, Schmitt and Smas' (2012) study of Nordic intercity connectivities, Lüthi et al.'s (2013) analysis of the relational geography of the knowledge economy in Germany, and Zhang and Kloosterman's (2016) study of the intra- and extra-service networks of the Pearl River Delta (see Table 1). In these studies, global connectivities are analysed using an 'egocentric' or 'hinter-world' perspective. Rather than analysing the world city network as a whole, these studies aim to identify the connectivity patterns within the corresponding regional or national urban system and its connections to selected destinations elsewhere.

\section{General analytical framework}

In technical terms, the INM uses a proxy - intra-firm networks of multi-branch, multi-location enterprises - to estimate potential flows of knowledge-creating information between cities (Taylor 2001). Once the relevant APS firms are identified, information is gathered on their office locations worldwide. The prime source of this information is the firms' corporate websites. It is necessary to scavenge all relevant information available online, supplemented by additional material such as annual reports or company brochures.

For each firm, two types of information are collected (Taylor et al. 2002): First, information about the size of a firm's presence in a city. In the best case, information can be found on the number of professionals working in each of the firm's offices. Secondly, information about the extra-locational functions of a firm's office in a city is gathered. This includes headquarters functions as well as other extra-territorial functions. Based on this information, all office locations are rated, typically on a scale of 0 to 5. A location that houses a company's headquarters scores 5. A location that houses a standard office scores 2. If an office has a special relevance within the firm network, the scoring is upgraded to 3 or 4 . If the overall importance of an office is low, the scoring is downgraded to 1 . The end result is a service activity matrix $\left(V_{i j}\right)$, defined by cities in the rows and firms in the columns. Each cell in the matrix shows the rating of an office location in a city: the service value $(v)$. This service activity matrix is used to calculate network connectivity, a measure that estimates how well connected a city is within the aggregated intra-firm network.

Here, different kinds of connectivity values can be calculated (Taylor 2001):

The connectivity between two cities ( $a, b)$ of a certain firm (j) is analysed by multiplying their service values $(v)$, representing the so-called elemental interlock $\left(r_{a b j}\right)$ between two cities for one firm:

$r_{a b j}=v_{a j} \cdot v_{b j}$

This approach seems reasonable when the following assumptions are made (Derudder and Taylor 2005, p. 74-75): 1) Offices generate more flows within their own firm network than to other firms in their sector. 2) More important offices generate more flows, which has a multiplicative effect on inter-city relations. Based on these assumptions, the elemental interlocks for all firms located in two cities are summarized, in order to calculate the total connectivity between the two cities. This leads to the so-called city interlock $\left(r_{a b}\right)$ :

$r_{a b}=\sum_{j} r_{a b j}$

Aggregating the city interlocks for a single city produces the interlock connectivity $\left(N_{a}\right)$. This measure describes the importance of a city within the intra-firm network of all analysed knowledge-intensive enterprises: 


$$
N_{a}=\sum_{i} r_{a i} \quad(a \neq i)
$$

Finally, relating the interlock connectivity for a given city to the city with the highest interlock connectivity in the sample shows its relative importance in relation to all other cities that have been considered. These scores - creating a scale from 0 to 1 - can be used to indicate hierarchical tendencies within the world city network.

The INM equations are a bipartite projection function where location information of agents (twomode: cities/agents) is transformed into information on inter-locational networks (one-mode: cities/cities). Various authors have since developed new analytical techniques in order to assess world city network data. Hennemann and Derudder (2014) for example propose an analytical framework using an algorithm that produces a one-mode directed graph based on the initial twomode network data of the INM. Neal (2013), on the other hand, suggests a new statistical test that permits the identification of linkages forged by a non-random firms-into-cities sorting process, instead of adopting the INM's 'brute force' perspective in which intercity linkages are forged by the cities' sheer economic size. In another recent paper, he adapts formal statistical methods used in network analysis to evaluate claims about the strength of cities' connectivities (Neal 2016). Yang et al. (2017), finally, introduce the idea of asymmetrical global network connectivity by distinguishing between the centrality of cities in 'sending' and 'receiving' flows. They find that the functional urban hierarchy in the world city network accentuates when looking solely at 'sending' cities. However, the additional analytical loops of these approaches also lead to new challenges in interpretation.

Even though the INM is an innovative way to calculate inter-city business relations, some limitations have to be acknowledged. The main limitation is the absence of extra-firm networks in its conceptualization. Intra-firm trade in transnational corporations accounts for an increasing share of international trade in today's global economy (OECD 2008), but intra-firm networks are only one set of relevant connections among many others (Coe et al. 2010). Information exchange and business activities arise not only through internal branch office networks, but also from the division of labour between different companies. It is now widely acknowledged that the most advanced activities of knowledge-intensive firms are deeply inscribed into external networks of suppliers, subcontractors and business clients. Extra-firm linkages are of increasing significance because firms have to rely not only on in-house knowledge, but also on resources external to the firm. To grasp these networks fully, it is necessary to analyse not only intra-firm connectivities but also the value chain relations between different enterprises and sectors. Even though there is still little cross-referencing between the world city network and the value chain literatures, they display a remarkable conceptual overlap and promise many methodological synergies and rich empirical findings (Derudder and Witlox 2010).

A second limitation is that the strength and importance of actual linkages between cities are not recorded by calculating city interlocks. Whether information is passing between cities by email, telephone or business travel can only be discovered by other means. The connectivity measures derived from the interlocking network model are therefore a proxy based on assumptions about the intensity of flows between offices. Nordlund (2004) for example criticized the assumption that the elemental interlock between two large office locations is greater than between a large and a small office location as there may in reality be more interaction between large and small offices because of command, control and support functions (Nordlund 2004). Even if this assumption is accepted for the global scale, where advanced producer service firms tend to operate across rather than through segmented markets (Sassen 1991), this may not hold true to the same extent for other scales. 
Multiple office locations within a nation state or large city-region, for example, may indicate intensive intra-firm flows but could also signal a subdivision into separate markets serviced by different office locations with few flows across (Hoyler et al. 2008b, p. 1097).

A third critique concerns the INM's potential for structural determinism (Neal 2012a; Liu and Derudder 2012, 2013). While Neal (2012) points out how the application of the INM in past GaWC analyses potentially constrains certain overall network structures and affects the analysis of city cliques and network density, Liu and Derudder (2012) argue that the practical implications are much less severe than suggested. Both papers call for an increased application of social network analysis to complement existing studies of the world city network.

\section{Empirical findings for Germany}

In the following section, we use the example of Germany to illustrate the potential benefits and limitations of applying a top-down or bottom-up approach to the study of city connectivities in a national context. For two reasons Germany is particularly interesting to evaluate the outcomes of the INM. On the one hand, the German national economy is strongly integrated globally and largely export-driven. Hence, several German cities are consistently ranked as important Alpha- or BetaCities according to GaWC research (http://www.lboro.ac.uk/gawc/gawcworlds.html). On the other hand, the German national urban system is characterized by a dense network of small and medium sized cities along with only a dozen bigger ones with populations of more than half a million inhabitants. In particular, the decentralized German federal government system has led to a distinctly polycentric urban system with no single city holding a clear dominant position (Knapp et al. 2006). It can be expected that in a balanced urban system such as the German one, the contrast between top-down and bottom-up approaches is particularly pronounced. In the case of a more monocentric national urban system such as in France or England, the differences between top-down and bottom-up might be less pronounced as business locations tend to concentrate in the primary city of the country. We draw on two datasets collected in 2008/2009 in close temporal proximity to ensure any differences in outcome are not due to change over time.

\section{The German urban system from a top-down perspective}

Taylor et al. (2011) utilize data collected on the global scale but focuses on the analysis of a subset that covers the external relations of German cities. Data were gathered in 2008 for 175 advanced producer service firms in 525 cities worldwide (Taylor et al. 2011). The firms were chosen for five APS sectors: finance ( 75 firms), accountancy, advertising, law and management consultancy ( 25 each) and represent the largest and most important firms as indicated by published rankings for the respective sectors (Hoyler 2011). Table 2 provides an overview of the distribution of offices by sector for different scales. Across all scales, accountancy firms are the most ubiquitous and corporate legal services the most concentrated sectors. However, even this basic comparison of office distributions reveals specificities of the German urban system, such as the exceptionally high number of law firm and management consultancy locations compared to the global distribution. This hints at particular sectoral strengths but is also an outcome of the federal territorial structure and distribution of key economic functions across a large number of cities and towns that makes international servicing from a single gateway city more difficult than in countries with a more primate urban system. 
Table 2: Top-down approach: studied APS sectors and their branches, 2008

\begin{tabular}{|c|c|c|c|c|}
\hline & Number of Firms & $\begin{array}{r}\text { Branches in } \\
\text { Germany }\end{array}$ & $\begin{array}{r}\text { Branches on the } \\
\text { European scale } \\
\text { (without Germany) }\end{array}$ & $\begin{array}{r}\text { Branches on the } \\
\text { global scale } \\
\text { (without Europe) }\end{array}$ \\
\hline $\begin{array}{l}\text { Financial Services } \\
\text { (Banking and Insurance) }\end{array}$ & 75 & 106 & 811 & 2.456 \\
\hline Accountancy & 25 & 166 & 998 & 2.893 \\
\hline Advertising & 25 & 68 & 607 & 1.407 \\
\hline Legal Services & 25 & 62 & 188 & 282 \\
\hline Management Consultancy & 25 & 85 & 399 & 951 \\
\hline
\end{tabular}

Note: There are 20 German, 96 other European and 409 non-European cities in the GaWC 2008 global data matrix of 525 cities $x 175$ firms. Multiple branches of one firm in one city are counted as one.

Network connectivities calculated on the basis of the 175 major APS firms used in the global approach identify 14 German cities that score at least 5 per cent of the highest ranked city globally, London (Hoyler 2011). Table 3 lists the top 10 cities, confirming Frankfurt's role as leading international financial centre, followed by a group of major German cities with similar levels of integration into the world city network: the capital Berlin, Hamburg and Munich as major economic centres in Northern and Southern Germany, and Düsseldorf as principal centre for international business services in Rhine-Ruhr. Frankfurt and Munich stand out as headquarter locations (service value 5), but Düsseldorf also houses a number of offices with extra-territorial functions (e.g. regional headquarters; service value 4). Command-and-control functions of the 175 largest global firms in advanced services are limited in Germany (six headquarters and 18 offices with extra-territorial functions) and highly concentrated, but all major German cities are well integrated through typically sized offices, ensuring that six German cities are among the 100 globally most integrated cities in advanced producer services. This contrasts starkly with the UK and France, whose global cities London and Paris rank 1 and 4 in the world in terms of their global network connectivity but where no other city is among the 100 most connected in the world (Taylor et al. 2011).

Table 3: Top-down approach: Interlock Connectivity and Service Values of the highest ranked German cities, 2008

\begin{tabular}{|c|c|c|c|c|c|c|c|c|c|}
\hline \multirow{2}{*}{$\begin{array}{l}\text { German } \\
\text { Rank }\end{array}$} & \multirow[b]{2}{*}{ City } & \multirow{2}{*}{$\begin{array}{r}\text { Gross } \\
\text { Connectivity }\end{array}$} & \multirow{2}{*}{$\begin{array}{r}\text { Proportionate } \\
\text { Connectivity } \\
\text { (1.00=London) }\end{array}$} & \multicolumn{5}{|c|}{ Number of Service Values } & \multirow{2}{*}{$\begin{array}{r}\text { Number of } \\
\text { office } \\
\text { locations }\end{array}$} \\
\hline & & & & 1 & 2 & 3 & 4 & 5 & \\
\hline 1 & Frankfurt & 48.165 & 0.50 & 0 & 65 & 28 & 8 & 3 & 104 \\
\hline 2 & Berlin & 37.825 & 0.39 & 0 & 16 & 30 & 1 & 0 & 47 \\
\hline 3 & Hamburg & 35.574 & 0.37 & 0 & 27 & 25 & 1 & 0 & 53 \\
\hline 4 & Munich & 33.482 & 0.35 & 0 & 60 & 9 & 1 & 3 & 73 \\
\hline 5 & Düsseldorf & 30.575 & 0.32 & 0 & 53 & 2 & 5 & 0 & 60 \\
\hline 6 & Stuttgart & 26.295 & 0.27 & 0 & 36 & 3 & 1 & 0 & 40 \\
\hline 7 & Cologne & 14.499 & 0.15 & 0 & 24 & 3 & 1 & 0 & 28 \\
\hline 8 & Leipzig & 11.762 & 0.12 & 0 & 15 & 0 & 0 & 0 & 15 \\
\hline 9 & Dresden & 11.628 & 0.12 & 0 & 15 & 0 & 0 & 0 & 15 \\
\hline 10 & Bremen & 9.916 & 0.10 & 0 & 13 & 0 & 0 & 0 & 13 \\
\hline
\end{tabular}


Whereas the top-down approach utilizes data collected on the global scale, Lüthi et al. (2013) take the national scale as the starting point for data collection. The final set of APS firms are defined by using data from the commercial data provider Hoppenstedt, complemented by business rankings, such as Forbes' Global 2000, Fortune's Global 500 and all firms listed in the prime standard of the Deutsche Börse. In order to be selected, the firms have to belong to the largest APS firms in Germany in their corresponding sub-sector, measured by employment size. They also need to be multi-branch enterprises with at least one office location in Germany. All in all, 180 APS firms in five sub-sectors are analysed here (Table 4). Financial services prove to be the most nationally based economic sector, which reflects the large networks of bank branches and other financial and insurance services supplying final demand. Accountancy and management consulting are the most global APS sectors. This information is important in order to assess the potential bias towards Germany in the bottom-up approach in comparison to the global top-down approach.

Table 4: Bottom-up approach: studied APS sectors and their branches, 2008/09

\begin{tabular}{|c|c|c|c|c|}
\hline & Number of Firms & $\begin{array}{r}\text { Branches in } \\
\text { Germany }\end{array}$ & $\begin{array}{r}\text { Branches on the } \\
\text { European scale } \\
\text { (without Germany) }\end{array}$ & $\begin{array}{r}\text { Branches on the } \\
\text { global scale } \\
\text { (without Europe) }\end{array}$ \\
\hline $\begin{array}{l}\text { Financial Services } \\
\text { (Banking and Insurance) }\end{array}$ & 60 & 1.598 & 639 & 653 \\
\hline Accountancy & 30 & 396 & 1127 & 1.240 \\
\hline Advertising & 30 & 231 & 336 & 301 \\
\hline Legal Services & 30 & 162 & 259 & 227 \\
\hline Management Consultancy & 30 & 248 & 901 & 1.064 \\
\hline
\end{tabular}

Lüthi et al.'s (2013) analytical focus is on Germany and its adjacent agglomerations in neighbouring countries, up to $50 \mathrm{~km}$ distance from the German border. All in all, the authors integrated 1.417 agglomerations from different continents and countries into the final data matrix. Table 5 shows the interlock connectivity of the top 10 German agglomerations from this bottom-up perspective: Frankfurt is top, followed by Munich, Berlin, Hamburg, Düsseldorf and Stuttgart. In comparison to the top-down approach discussed above, there are minor differences in outcome: Munich ranks higher, but note that ranks 2 to 5 in the top-down approach are very close together. Furthermore, Nuremberg and Hanover replace Leipzig and Bremen in the top 10.

Table 5: Bottom-up approach: Interlock Connectivity and Service Values of the highest ranked German cities, 2008/09

\begin{tabular}{|c|c|c|c|c|c|c|c|c|c|}
\hline \multirow{2}{*}{$\begin{array}{l}\text { German } \\
\text { Rank }\end{array}$} & \multirow{2}{*}{ City } & \multirow{2}{*}{$\begin{array}{r}\text { Gross } \\
\text { Connectivity }\end{array}$} & \multirow{2}{*}{$\begin{array}{r}\text { Proportionate } \\
\text { Connectivity } \\
\text { (1.00=London) }\end{array}$} & \multicolumn{5}{|c|}{ Number of Service Values } & \multirow{2}{*}{$\begin{array}{l}\text { Number } \\
\text { of office } \\
\text { locations }\end{array}$} \\
\hline & & & & 1 & 2 & 3 & 4 & 5 & \\
\hline 1 & Frankfurt & 40.896 & 0.85 & 1 & 61 & 19 & 9 & 12 & 102 \\
\hline 2 & Munich & 37.196 & 0.78 & 1 & 60 & 21 & 7 & 15 & 104 \\
\hline 3 & Berlin & 36.170 & 0.75 & 5 & 51 & 28 & 7 & 6 & 97 \\
\hline 4 & Hamburg & 33.568 & 0.70 & 4 & 58 & 15 & 9 & 9 & 95 \\
\hline 5 & Düsseldorf & 28.961 & 0.60 & 3 & 45 & 16 & 5 & 6 & 75 \\
\hline 6 & Stuttgart & 28.920 & 0.60 & 2 & 40 & 16 & 3 & 8 & 69 \\
\hline 7 & Cologne & 24.920 & 0.52 & 3 & 36 & 15 & 3 & 11 & 68 \\
\hline 8 & Nuremberg & 23.166 & 0.48 & 2 & 30 & 4 & 0 & 4 & 40 \\
\hline
\end{tabular}




\begin{tabular}{|c|c|c|c|c|c|c|c|c|c|}
\hline \multirow{2}{*}{$\begin{array}{l}\text { German } \\
\text { Rank }\end{array}$} & \multirow[b]{2}{*}{ City } & \multirow{2}{*}{$\begin{array}{r}\text { Gross } \\
\text { Connectivity }\end{array}$} & \multirow{2}{*}{$\begin{array}{r}\text { Proportionate } \\
\text { Connectivity } \\
(1.00=\text { London) }\end{array}$} & \multicolumn{5}{|c|}{ Number of Service Values } & \multirow{2}{*}{$\begin{array}{l}\text { Number } \\
\text { of office } \\
\text { locations }\end{array}$} \\
\hline & & & & 1 & 2 & 3 & 4 & 5 & \\
\hline 9 & Dresden & 21.498 & 0.45 & 0 & 37 & 7 & 0 & 0 & 44 \\
\hline 10 & Hanover & 20.857 & 0.44 & 3 & 29 & 5 & 1 & 8 & 46 \\
\hline
\end{tabular}

In terms of headquarter functions; Munich ranks first, with 15 APS headquarters, followed by Frankfurt (12) and Cologne (11). This finding confirms the importance of Munich and Frankfurt as leading German command-and-control centres in the APS sector. The corporate headquarters in these cities are responsible for all the major strategic investment decisions that shape the intra-firm networks of the whole enterprise.

\section{Discussion}

As demonstrated above, the top-down and the bottom-up approach produce similar results, which confirms the general robustness of the INM: Frankfurt, Munich, Berlin, Hamburg, Düsseldorf and Stuttgart form part of an "urban circuit" that constitutes the top of the German functional urban hierarchy (Hoyler et al. 2008b, p. 1102). In terms of the shape of this hierarchy, however, there are substantial differences between both approaches (Figure 1). From the global top-down perspective, the German space economy appears much less polycentric than from the national bottom-up perspective, due to a higher degree of spatial concentration of the largest globally operating APS firms. Nevertheless, the German urban system still shows a comparatively high degree of polycentricity, even in the top-down perspective, when compared to national urban systems with a dominating capital city such as the UK or France (Taylor et al. 2011).

Proportionate Connectivity $(1.00=$ Frankfurt $)$

Top-down

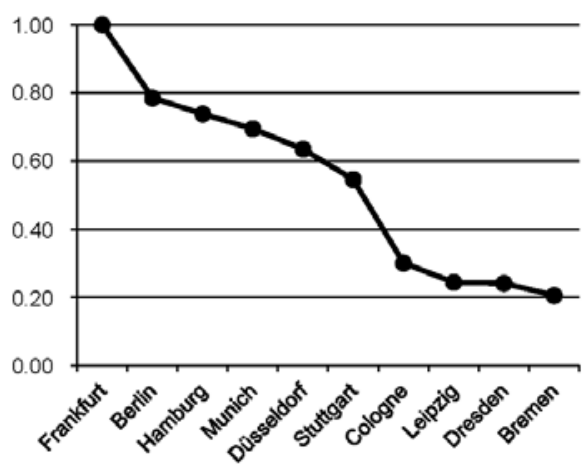

Bottom-up

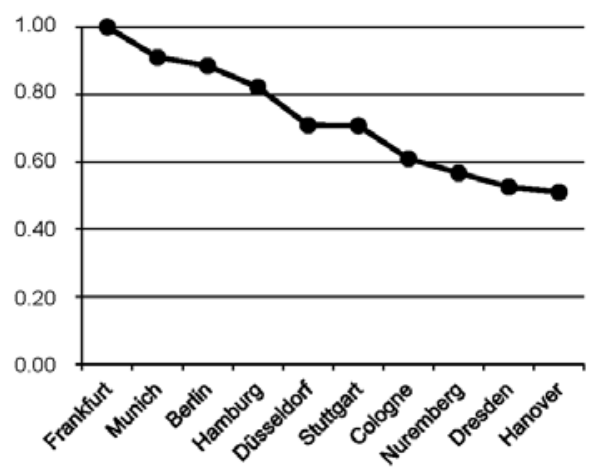

Figure 1: Top-down vs bottom-up: functional urban hierarchies in Germany, 2008/09

The question arises of the relative merits of each approach for the analysis of external relations of cities. In order to identify the causes of the discrepancies between the top-down and the bottom-up approach, we formulate a number of theses that will be discussed further:

(i) The INM can be applied on a range of scales using top-down and bottom-up perspectives.

The INM creates the most reliable results if the firms are selected on the spatial scale to which the analysis primarily refers: a global analysis should capture the largest global firms; a regional analysis 
should capture the firms with the most significant regional presence. The largest global firms may also be used for a national/regional analysis, but only if enough of these firms have office locations in the corresponding agglomerations. The most significant regional firms may also be used for a global analysis, but only in order to assess the city-interlocks to global destinations. In the bottom-up perspective, for example, it is possible to assess the link between Hamburg and New York, but not the link between Tokyo and New York or the position of Hamburg and New York in the whole world city network.

(ii) Independent of scalar approach, the INM can be used as a generic model to assess the integration of cities into networks of a variety of economic and other actors.

According to Sassen (1991), APS firms create world-wide office networks covering major cities in most or all world regions through their transnational spatial strategies. International high-tech firms, however, pursue similar strategies. Several authors show that high-tech firms are on average more globalized than APS firms (OECD 2008; Lüthi et al. 2013; Krätke 2014). Clearly-defined technical standards in high-tech production reduce the risk of misunderstandings to such a degree that even complex information can be communicated over long distances (Gereffi et al. 2005). Hence, by limiting the INM to describe only the details of APS networks, a chance is missed to make the findings work more analytically. Sassen $(2010$, p. 156) herself underlines that the integration of high-tech sectors is an important complement and enrichment of analysing cities in globalization.

However, APS and high-tech firms are not the only agents that interlock cities in contemporary globalization. Other 'global networkers' include, for example, media corporations (Krätke and Taylor 2004; Hoyler and Watson 2013), non-governmental organizations, UN agencies and diplomatic missions (Taylor 2005). Indeed, a case can be made for the INM as a generic model for understanding 'cityness' in terms of external inter-city relations (Taylor et al. 2010; Taylor 2012; Derudder and Taylor 2017).

(iii) The INM provides more robust results by analysing a restricted number of cities worldwide.

In order to analyse this thesis, let us recall the calculation of the INM. The INM calculates the interlock connectivity, a measure of how strong a city is integrated into the world city network through intra-firm networks of knowledge-intensive firms: a high interlock connectivity is the result of three parameters: (1) a large number of office locations in a city, (2) a large size of the corresponding firms in terms of office locations worldwide, and (3) a high rating of the respective service values.

Regarding the first parameter, the question arises how many firms have to be present in a city in order to produce reliable connectivity values? If the data of the global top-down approach are evaluated on the national or even regional scale, the connectivity values might refer to very few companies, especially in small and medium sized cities and towns. Thereby, the key principle of empirical aggregation gets lost. A robustness analysis of the INM suggests that at least 25 firms per city should be used (Taylor 2004). In this regard, the bottom-up approach, which focuses on Germany and its adjacent agglomerations, includes several advantages. The selection of the biggest Germanybased firms enables a fine grained covering of the study area with a multiplicity of cities. This, in turn, makes it possible to identify the role of small and medium sized cities and towns that are located at the peripheries of - or between - the main mega-city regions. Furthermore, the inclusion of adjacent 
agglomerations up to $50 \mathrm{~km}$ distance from the German border makes it possible to identify and contextualize large-scale urban structures and hierarchies of cross border agglomerations.

The second parameter - the firm size in terms of office locations worldwide - also has a lasting effect on the INM, particularly in the bottom-up approach. Since the latter studies a very large number of cities worldwide - 1,417 in total in our German case study - the size of one APS firm becomes highly significant for the interlock connectivity of a city. PricewaterhouseCoopers, for example, has over 700 office locations worldwide. Because of the adding-up of over 700 elemental interlocks, PricewaterhouseCoopers becomes very important for a single agglomeration, especially in small agglomerations with only very few other APS firms. Hence, in order to reduce the influence of a single firm on the interlock connectivity in small agglomerations - and thereby to stabilize the INM the maximum number of cities in the whole network analysis should be restricted.

Similarly, the third parameter - the rating of service values - calls for a limitation of the number of cities analysed. This is due to the potential for uncertainty in the connectivity values that results from the subjectively assigned scores that rate the importance of a city within a firm's office network. A robustness analysis of the global approach suggests that connectivity values derived from the INM for the top 130 cities are relatively insusceptible to significant rank shifts, but that lower-ranked cities are more sensitive to changes in service values (Liu and Taylor 2011).

\section{Conclusions}

One of the most important aspects of the INM is that it analyses the spatial patterns of the knowledge economy by putting the activities of the firms - their strategic decisions and organizational structures - at the centre of the argument. In both its manifestations as a top-down or bottom-up approach, the INM provides an empirical instrument for quantifying inter-city relations in terms of the organizational structure of the global knowledge economy.

The key advantage of using a top-down approach for the analysis of cities in a specific national context lies in its provision of globally comparable data and measures. These allow the exploration of national and macro-regional contrasts, for example the different degrees of primacy in 'national urban systems' based on a measure of economic integration (global network connectivity) rather than population size. Other relevant measures include comparative evaluations of the orientation of the external relations of individual cities, for example the degree to which they are relatively over or under linked to leading cities in the world economy (e.g. New York - London), or to cities within their own national context (Taylor et al. 2011). All of these comparative analyses can also be disaggregated in sectoral analyses of the constituent advanced producer service sectors.

However, disaggregation is where a global approach reaches its limits fairly quickly. Although the firms included in the analysis are generally the leading global firms, with operations across a wide number of countries, their number in each sector is relatively small. Their role can perhaps best be described as that of an "indicator species" (Taylor 2014:394), highlighting the major patterns of connectivity in advanced servicing but unable to capture the myriad of extensive linkages that exist beyond the key global players. This is particularly significant for analyses of smaller and economically less dominant places in the economy that may well be linked into global processes via smaller multicity firms with national or transnational scope (Zhao et al. 2015). Equally, those interested in detailed analyses of advanced service firm location in larger metropolitan regions may find that the global data offer limited if any options to explore city-regional divisions of labour in advanced producer 
servicing. This is where a bottom-up approach can significantly extend the application of the interlocking network model.

For future research, however, it will be important to learn more about the locational strategies that shape the world city network. There is a need to reveal the more subtle and strategic processes underlying the spatial activities of the knowledge economy and to get inside the black box of the INM, for example through qualitative methods (Lambregts 2008; Watson and Beaverstock 2014). Opening-up the world city network perspective to related academic debates, such as the literature in regional science on agglomeration and network economies (Burger et al. 2014), promises rich potential for advancing the conceptualization of functional economic relations at different spatial scales. Our evaluation of top-down versus bottom-up approaches to understanding the world city network can serve as a first step in this direction.

\section{References}

Bentlage, Michael; Thierstein, Alain and Lüthi, Stefan (2016): Von Zentralen Orten zu Zentralen Knoten. Über Zentralität, Konnektivität und Spezialisierung in den Metropolregionen München und Stuttgart. In: Rainer Danielzyk, Angelika Münter, Thorsten Wiechmann (Eds), Polyzentrale Metropolregionen (225-248). Detmold: Verlag Dorothea Rohn.

Burger, Martijn J., Meijers, Evert J. and van Oort, Frank G. (2014): Multiple perspectives on functional coherence: heterogeneity and multiplexity in the Randstad. In: Tijdschrift voor Economische en Sociale Geografie 105(4): 444-464.

Castells, Manuel (1996): The Rise of the Network Society. The Information Age: Economy, Society and Culture, Vol. 1, 1. Ed. Malden: Blackwell.

Castells, Manuel (2000): The Rise of the Network Society. The Information Age: Economy, Society and Culture, Vol. 1, 2. Ed. Malden: Blackwell.

Chow, Alice S.Y. and Becky P.Y. Loo (2015): Applying a world-city network approach to globalizing higher education: Conceptualization, data collection and the list of world cities. Higher Education Policy 28: 107-126. DOI:10.1057/hep.2014.31.

Coe, Neil; Dicken, Peter; Hess, Martin and Yeung, Henry Wai-Cheung (2010): Making connections: global production networks and world city networks. In: Global Networks 10(1): 138-149.

Derudder, Ben and Parnreiter, Christof (2014): Introduction: The interlocking network model for studying urban networks: outline, potential, critiques, and ways forward. In: Tijdschrift voor Economische en Sociale Geografie 105(4): 373-386.

Derudder, Ben and Taylor, Peter J. (2005): The cliquishness of world cities. In: Global Networks 5(1): 71-91.

Derudder, Ben and Taylor, Peter J. (2016): Change in the world city network. In: The Professional Geographer 68(4): 624-637.

Derudder, Ben and Taylor, Peter J. (2017): Central flow theory: comparative connectivities in the world-city network. In: Regional Studies DOI:10.1080/00343404.2017.1330538.

Derudder, Ben; Taylor, Peter J.; Ni, Pengfei; De Vos, Anneleen; Hoyler, Michael; Hanssens, Heidi; Bassens, David; Huang, Jin; Witlox, Frank; Shen, Wei and Yang, Xiaolan (2010): Pathways of change: Shifting connectivities in the world city network, 2000-08. In: Urban Studies 47(9): 1861-1877.

Derudder, Ben and Witlox, Frank (ed.) (2010): Commodity Chains and World Cities. Chichester: WileyBlackwell.

Derudder, Ben, Taylor, Peter J., Hoyler, Michael, Ni, Pengfei, Liu, Xingjian, Zhao, Miaoxi, Shen, Wei and Witlox, Frank (2013): Measurement and interpretation of connectivity of Chinese cities in world city network, 2010. Chinese Geographical Science 23(3): 261-273.

Friedmann, John (1986): The world city hypothesis. In: Development and Change 17: 69-83. 
Gereffi, Gary; Humphrey, John and Sturgeon, Timothy (2005): The governance of global value chains. In: Review of International Political Economy 12(1): 78-104.

Growe, Anna and Blotevogel, Hans. H. (2011): Knowledge hubs in the German urban system: Identifying hubs by combining network and territorial perspectives. In: Raumforschung und Raumordnung, 69(3), 175-185.

Growe, Anna and Volgmann, Kati (2016): Exploring cosmopolitanity and connectivity in the polycentric German urban system. In: Tijdschrift voor Economische en Sociale Geografie 107(2): 214-231.

Hall, Peter (2001): Global city-regions in the twenty-first century. In: Scott, Allen J. (ed.), Global CityRegions. Trends, Theory, Policy. New York: Oxford University Press: 59-77.

Hall, Peter (2009): Looking backward, looking forward: the city region of the mid-21st century. In: Regional Studies 43(6): 803-817.

Hall, Peter and Pain, Kathy (eds) (2006): The Polycentric Metropolis: Learning from Mega-City Regions in Europe. London: Earthscan.

Hanssens, Heidi; Derudder, Ben; Taylor, Peter J.; Hoyler, Michael; Ni, Pengfei; Huang, Jin; Yang, Xiaolan and Witlox, Frank (2011): The changing geography of globalized service provision, 2000-2008. In: The Service Industries Journal 31(14): 2293-2307.

Hennemann, Stefan and Derudder, Ben (2014): An alternative approach to the calculation and analysis of connectivity in the world city network. In: Environment and Planning B: Planning and Design, 2014(41): 392-412.

Hoyler, Michael (2011): External relations of German cities through intra-firm networks - a global perspective. In: Raumforschung und Raumordnung 69(3): 147-159.

Hoyler, Michael; Freytag, Tim and Mager, Christoph (2008b): Connecting Rhine-Main: The production of multi-scalar polycentricities through knowledge-intensive business services. In: Regional Studies 42(8): 1095-1111.

Hoyler, Michael; Kloosterman, Robert C. and Sokol, Martin (2008a): Polycentric puzzles - Emerging mega-city regions seen through the lens of advanced producer services. In: Regional Studies 42(8): 1055-1064.

Hoyler, Michael and Watson, Allen (2013): Global media cities in transnational media networks. In: Tijdschrift voor Economische en Sociale Geografie 104(1): 90-108.

Knapp, Wolfgang; Scherhag, Daniela and Schmitt, Peter (2006): RhineRuhr: Polycentricity at its best? In: Hall, Peter and Pain, Kathy (ed.), The Polycentric Metropolis. Learning From Mega-City Regions in Europe. London: Earthscan: 154-162.

Krätke, Stefan (2014): How manufacturing industries connect cities across the world: Extending research on multiple globalizations. In: Global Networks, 14(2): 121-147.

Krätke, Stefan and Taylor, Peter J. (2004): A world geography of global media cities. In: European Planning Studies 12(4): 459-477.

Lambregts, Bart (2008): Geographies of knowledge formation in mega-city regions: Some evidence from the Dutch Randstad. In: Regional Studies 42(8): 1173-1186.

Liu, Xingjian and Derudder, Ben (2012): Two-mode networks and the interlocking world city network model: a reply to Neal. In: Geographical Analysis, 44, 2: 171-173.

Liu, Xingjian and Derudder, Ben (2013): Analyzing urban networks through the lens of corporate networks: a critical review. In: Cities, 2013(31): 430-437.

Liu, Xingjian, Derudder, Ben, Witlox, Frank and Hoyler, Michael (2014): Cities as networks within networks of cities: the evolution of the city/firm-duality in the world city network, 20002010. In: Tijdschrift voor Economische en Sociale Geografie 105(4): 465-482.

Liu, Xingjian and Taylor, Peter J. (2011): A robustness assessment of global city network connectivity rankings. In: Urban Geography 32(8): 1227-1237.

Lüthi, Stefan; Thierstein, Alain and Bentlage, Michael (2013): The relational geography of the knowledge economy in Germany. On functional urban hierarchies and localised value chain systems. In: Urban Studies 50(2): 276-293. 
Lüthi, Stefan; Thierstein, Alain and Bentlage, Michael (2016): Metropolregion Nordschweiz: zu gross um wahr zu sein? In: Rainer Danielzyk, Angelika Münter, Thorsten Wiechmann (Eds), Polyzentrale Metropolregionen (272-290). Detmold: Verlag Dorothea Rohn.

Lüthi, Stefan; Thierstein, Alain and Goebel, Viktor (2010): Intra-firm and extra-firm linkages in the knowledge economy: the case of the emerging mega-city region of Munich. In: Global Networks 10(1): 114-137.

Martinus, Kirsten and Tonts, Matthew (2015): Powering the world city system: energy industry networks and inter-urban connectivity. Environment and Planning A, 47(7), 1502-1520.

Münter, Angelika (2011): Germany's polycentric metropolitan regions in the world city network. In: Raumforschung und Raumordnung, 69(3), 187-200.

Neal, Zachary (2012): Structural determinism in the interlocking world city network. In: Geographical Analysis 44(2): 162-170.

Neal, Zachary (2013): Brute force and sorting processes: two perspectives on world city network formation. In: Urban Studies 50(6): 1277-1291.

Neal, Zachary P. (2016): Well connected compared to what? Rethinking frames of reference in world city network research. In: Environment and Planning A DOI: 10.1177/0308518X16631339.

Nordlund, Carl (2004): A critical comment on the Taylor approach for measuring world city interlock linkages. In: Geographical Analysis 36(3): 290-296.

OECD (ed.) (2008): Staying Competitive in the Global Economy. Paris: OECD.

Sassen, Saskia (1991): The Global City: New York, London, Tokyo. Princeton, NJ: Princeton University Press.

Sassen, Saskia (2001): The Global City: New York, London, Tokyo, 2nd Edition, Princeton: Princeton University Press.

Sassen, Saskia (2010): Global inter-city networks and commodity chains: any intersections? In: Global Networks 10(1): 150-163.

Schmitt, Peter and Smas, Lukas (2012): Nordic 'intercity connectivities' in a multi-scalar perspective. In: Nordregio Working Paper, 2012:7, http://www.nordregio.se, accessed 06.07.2012.

Sigler, Thomas \& Martinus, Kirsten. (2016): Extending beyond 'world cities' in world city network (WCN) research: Urban positionality and economic linkages through the Australia-based corporate network. Environment and Planning A. doi:10.1177/0308518X16659478.

Taylor, Peter J. (1997): Hierarchical tendencies amongst world cities: a global research proposal. In: Cities 14(6): 323-332.

Taylor, Peter J. (2001): Specification of the world city network. In: Geographical Analysis 33(2): 181194.

Taylor, Peter J. (2004): World City Network: A Global Urban Analysis. London: Routledge.

Taylor, Peter J. (2005): Leading world cities: empirical evaluations of urban nodes in multiple networks. In: Urban Studies 42(9): 1593-1608.

Taylor, Peter J. (2012): The interlocking network model. In: Derudder, Ben; Hoyler, Michael; Taylor, Peter J. and Witlox, Frank (ed.), International Handbook of Globalization and World Cities. Cheltenham: Edward Elgar: 51-63.

Taylor, Peter (2014): A research odyssey: From interlocking network model to extraordinary cities. In: Tijdschrift voor Economische en Sociale Geografie, Vol. 105, No. 4, pp. 387-397.

Taylor, Peter J.; Catalano, Gilda and Walker, David R. F. (2002): Exploratory analysis of the world city network. In: Urban Studies 39(13): 2377-2394.

Taylor, Peter J. and Derudder, Ben (2016): World City Network: A Global Urban Analysis. 2nd edition. London: Routledge.

Taylor, Peter J.; Evans, David M.; Hoyler, Michael; Derudder, Ben and Pain, Kathy (2009): The UK space economy as practised by advanced producer service firms: Identifying two distinctive polycentric city-regional processes in contemporary Britain. In: International Journal of Urban and Regional Research 33: 700-718.

Taylor, Peter J.; Evans, David M. and Pain, Kathy (2008): Application of the interlocking network model to mega-city-regions: Measuring polycentricity within and beyond city-regions. In: Regional Studies 42(8): 1079-1093. 
Taylor, Peter J.; Hoyler, Michael and Verbruggen, Ralf (2010): External urban relational process: Introducing central flow theory to complement central place theory. In: Urban Studies 47(13): 2803-2818.

Taylor, Peter J.; Ni, Pengfei; Derudder, Ben; Hoyler, Michael; Huang, Jin and Witlox, Frank (eds.) (2011): Global Urban Analysis: A Survey of Cities in Globalization. London: Earthscan.

Taylor, Peter J.; Derudder, Ben; Hoyler, Michael and Ni, Pengfei (2013): New regional geographies as practised by leading advanced producer service firms in 2010. In: Transactions of the Institute of British Geographers, 38(3): 497-511.

Taylor, Peter J.; Derudder, Ben; Faulconbridge, James; Hoyler, Michael and Ni, Pengfei (2014): Advanced producer service firms as strategic networks, global cities as strategic places. In: Economic Geography, 90(3): 267-291.

Thierstein, Alain; Lüthi, Stefan; Kruse, Christian; Gabi, Simone and Glanzmann, Lars (2008): Changing value chain of the knowledge economy. Spatial impact of intra-firm and inter-firm networks within the emerging Mega-City Region of Northern Switzerland. In: Regional Studies 42(8): 1113-1131.

Watson, Allan and Beaverstock, Jonathan V. (2014): World city network research at a theoretical impasse: on the need to re-establish qualitative approaches to understanding agency in world city networks. In: Tijdschrift voor Economische en Sociale Geografie 105(4): 412-426.

Yang, Xiaolan; Derudder, Ben; Taylor, Peter J.; Ni, Pengfei and Shen, Wei (2017): Asymmetric global network connectivities in the world city network, 2013. In: Cities 60: 84-90.

Zhang, X. (2017): Multiple creators of knowledge-intensive service networks: A case study of the Pearl River Delta city-region. In: Urban Studies DOI: 10.1177/0042098017700805.

Zhang, Xu and Kloosterman, Robert (2016): Connecting the 'workshop of the world': intra- and extraservice networks of the Pearl River Delta City-Region. In: Regional Studies 50(6): 1069-1081.

Zhao, M., Liu, X., Derudder, B., Zhong, Y. and Shen, W. (2015): Mapping producer service networks in mainland Chinese cities. In: Urban Studies 52(16): 3018-3034. 